\title{
MACROECONOMIC DETERMINANTS OF CORPORATE FAILURES. EVIDENCE FROM ROMANIA AND SPAIN
}

\author{
Ion ANGHEL ${ }^{1}$, Calcedonia ENACHE (D2 ${ }^{*}$, Fernando MERINO (D) 3 \\ ${ }^{1}$ The Faculty of Accounting and Management Information Systems, \\ Bucharest University of Economic Studies, Bucharest, Romania \\ ${ }^{2}$ The Faculty of Business and Tourism, Bucharest University of Economic Studies, \\ Bucharest, Romania \\ ${ }^{3}$ Faculty of Economics and Business, University of Murcia, Murcia, Spain
}

Received 27 November 2018; accepted 21 January 2020

\begin{abstract}
The purpose of this study is to investigate the reaction of the insolvency rate to the various shocks in the economies of Romania and Spain through a Structural Vector Autoregressive model. Departing from quarterly data for 2008-2016, it was found that the future values of the insolvency rate are explained by the past values of the interest rate and the retail trade index, more precisely macroeconomic risk factors cost of debt and changing in demand are main responsible for the health of non-financial corporations sector. In contrast, the influence of the investment rate on insolvency rate is not predictable. In addition, both in Romania and in Spain the interest rate is the main determinant of the insolvency rate variation, beyond its own innovations, in horizons of over 2 quarters. These results were obtained under the circumstances that the analysed period was characterized by the Great Recession and its recovery. In this situation, firms faced a lesser demand as well as a tightening on the possibilities of obtaining the external funds they needed, not only to finance their expansion projects but even their daily operations. Consequently, many firms faced a negative environment that forced them to go out of the market.
\end{abstract}

Keywords: companies' failure, macroeconomic factors, cointegration analysis, VAR model, Spain, Romania.

JEL Classification: C3, D5, G3, D53, M21.

\section{Introduction}

The importance of the non-financial corporate sector in developing, transferring or intensifying economic turbulences has been analysed in the last decades. The majority of papers argues that a large proportion of firms in a weak or risky financial situation can be responsible for a deeper and longer recession or even be the trigger of an economic recession departing

\footnotetext{
${ }^{\star}$ Corresponding author. E-mails calcedoniaenache@yahoo.com

This article was originally published with error. This version has been amended.

Please see Erratum https://doi.org/10.3846/jbem.2020.12595

Copyright (C) 2020 The Author(s). Published by VGTU Press

This is an Open Access article distributed under the terms of the Creative Commons Attribution License (http://creativecommons. org/licenses/by/4.0/), which permits unrestricted use, distribution, and reproduction in any medium, provided the original author and source are credited.
} 
from a financial crisis, since a financial turmoil (such as a credit shortage or an increase in interest rates) may lead to some firms to close, which will increase unemployment, reduce domestic demand of intermediate inputs, etc. In this context, research to find the correlation between the corporate insolvency and macroeconomic variables becomes useful and relevant in decision making and predictions regarding the economic fragility. The analysis of company's insolvencies is important since it is an important sign for the weakness of the firms with major consequences over the entire macroeconomic equilibrium. Besides, corporate failures are directly responsible for the erosion of the capital level of banks since they generate losses in their investments.

The analysis of firms' bankruptcy has largely used a microeconomic perspective aiming to determine the reasons that lead a specific firm to be in a financial distress situation. However, the macroeconomic environment has also been revealed as in important reason of this situation. One of the earliest analyses of the situation of non-financial firms along financial crises was realized by Fisher (1933) which looks at the interaction between relative level of debt and price level turbulences. The underlying theory is simple: firms with a high level of debt will be under higher financial pressure during an economic period with low or negative growth rates, since the impact of a demand reduction usually is not compensated by the possible reduction in financial costs (if interest rates are reduced as an economic policy to circumvent the crisis, which not always happens as it was the case in the first years after the 2008 financial crisis in the Euro-area). To satisfy creditors' requests, the companies are forced to sell assets and reduce deposits in order to repay their loans. Such sale of assets and decrease in the deposits reduces net worth of companies (both for the costs of doing that but for the lower prices that are usually accepted when a firm needs of additional liquidity) becoming more vulnerable and increasing the probability of failure. Besides, a decrease in the level of deposits and loan repayment creates a shock in money velocity which will decrease asset prices and then an additional negative shock that will affect companies. Then, the financial weakness of the corporate sector will negatively influence the banks' willingness to lend money to companies.

This paper fits in the macroeconomic approach of the question, analysing the aggregate figures of insolvencies for Romania. It must be noted that most of the existing literature is focused on the microeconomic perspective that aims to look for scoring models to predict individual firms' insolvencies. For example, papers such as Smaranda (2014) have analyzed the question from a microeconomic perspective, focusing on the firms' determinants for bankruptcy concluding that some of the determinants differ in a financial crisis environment. Different papers have remarked that the institutional framework can be relevant in the importance that macroeconomic factors may have on insolvencies and, consequently, the design of the insolvency legislation, the efficiency of the judiciary system, etc. become important factors for a higher or lower percentage of firm bankruptcies with the same macroeconomic environment (for instance Dăianu, Pîslaru, and Voinea (2004) analyze it in comparison to other EU members as one of the topics that countries such as Romania should consider in their accession to EU; Beca and Nișulescu (2014) also compare the Romanian situation with EU in order to propose specific measures to improve the situation). Recent papers conclude that "actual accuracy of bankruptcy models is lower than original accuracy indicated by model makers" (Kuběnka \& Myšková, 2019) a possible explanation being related with macroeconomic and country specific elements. So, given the importance that country specific 
features may have, we are going to present the Romanian results in comparison with one of the core EU countries. We have chosen Spain as reference since it is one of the euro area members, which supposes that experienced interest rates that are consequence of the European Central Bank policies not specially focused on the Spanish situation. Besides, Spain is among the top $5 \mathrm{EU}$ economies, the one where the economic recession, measured in terms of GDP reduction, unemployment, etc. had the deepest impact. The analysis of macroeconomic determinants impact on the microeconomic risk is an important area for research, recent papers considering this topic from different prospective like us specific company's risk (Gonzalalez et al., 2018) or expected growth risk (Došenović Bonča et al., 2018).

The paper is structured as follows. After the introduction, a section describes summarily the situation of the two countries in order to frame the analysis. Section 3 presents some of the key papers in the analysis of the insolvencies in a country from an aggregate perspective. The fourth section presents the employed methodology and the fifth the data and the results of the model. Sixth section discusses the results and the paper ends with the conclusions and some future research lines.

\section{Bankruptcies in Romania and Spain}

Bankruptcies are a phenomenon inherent to firms' life that is specifically regulated by national laws. Basically, it supposes that a firm is in a financial situation where it cannot face its payments and needs a deep reorganization or even liquidation (Anghel, 2002). There is no international legislation on bankruptcies, although UNCITRAL and the World Bank have established some goals that it should have in the (Principles for Effective Insolvency and Creditor Rights Systems) since scholars agree that a well-designed legislation may encourage market efficiency (Stiglitz, 2003). In Romania, the law that defines insolvencies, as well as all the legal procedures inherent to this case, is the Law 85/2014, meanwhile, in Spain it is the Law 22/2003 (its details are summarized in Dăianu et al., 2004). Both countries legislation is based on the UNCITRAL recommendations.

Given the evolution of the economy, in Romania as in most of the countries, the evolution of insolvencies along 2008-2016 experienced important variations. Thus, in 2008, the insolvency rate amounted to 3.09 percent, in a situation where the indicator of the economic sentiment had been deteriorating progressively over the last 3 months of the year. The insolvency rate increased from 3.28 percent in 2009 to 4.87 percent in 2010, as a result of the decline in activity, in the context of the domestic consumption and investment contraction, the high leverage effect and the depreciation of the domestic currency. The insolvency rate stood at 5.08 percent in 2011, raised to 5.67 percent in 2012 and to 6.04 percent in 2013, in the condition that the real annual growth rate of the loans to non-financial corporations became negative, and a large proportion of managers preferred to finance their investments from internal resources. In the interval 2014-2016, the insolvency rate declined from 4.06 percent to 1.49 percent, under the impact of a slight improvement in lending conditions, a reduction in the policy rate coupled with a decrease in inflation, an increase in the volume of new orders, the entry into force of the new insolvency code in June 2014. The new legal framework stipulates a threshold value of RON 40,000 (EUR 9,000 approximately) both for creditors and the debtor in order to file the application for insolvency proceedings (the mini- 
mum amount of the claim in order for the creditor's application to be filed was RON 10,000 (EUR 2,837), by Law no. 85/2006 and subsequently amended to RON 30,000 (EUR 7,080) by Law no. 277/2009 and RON 45,000 (EUR 10,689) by Law 169/2010) and a maximum duration of the observation period, calculated between the date of opening the insolvency proceedings and the date of confirmation of the organizational plan or, as the case may be, of the entry into bankruptcy, for 12 months (the previous legislation did not provide for a maximum duration). This behaviour was, more or less similar to the one of our country of reference that also suffered the financial crisis and its recovery. In Spain the insolvency rate that was 0.08 percent in 2008 more than doubled in 2009 to arrive to 0.18 percent with a lower value in 2010 of 0.15 percent to start a three year growth of 0.18 percent in 2011 and 0.25 percent in 2012 and 0.29 percent in 2013. Those were years of a deep crisis on the Spanish economy as the economic sentiment index indicates that reduced from 112 in 2007 to 95 in 2012 and 99 in 2013. That year supposed the beginning of the recovery in a continuous path that in 2016 got a sentiment index of 114.7. Hand to hand, the bankruptcy rate decreased to 0.21 percent in 2014, 0.16 percent in 2015 and 0.13 percent in 2016.

In 2016, according to the statistical data published by the National Bank of Romania, insolvent companies created around 2 percent of the turnover achieved by non-financial companies and held 4 percent of the number of employees of this sector. For this category of companies, return on assets (ROA) fluctuated in the interval 2008-2016 between 3.44 percent and -11.93 percent, while at the level of non-financial companies the indicator varied between 1.69 percent and 3.50 percent. The share of loans granted to insolvent companies in the total volume of loans to the non-financial corporations sector rose gradually from 1.1 percent in 2008 to 19.7 percent in 2013, followed by a downward trend of up to 15.0 percent in 2015, which was succeeded by a return to higher values in the last months of 2016. Incidentally, the volume of non-performing loans granted by banks to insolvent companies had an average annual growth rate of 1.56 times during the interval December 2008-December 2016 (reaching more than EUR 3700 million) (Figure 1).

In Spain, the situation was slightly different, since the economic and financial crisis was deeper and it took more time to re-take a growth path. This is in accordance with other researches which find that the crisis on some member states (Portugal, Spain and Greece)

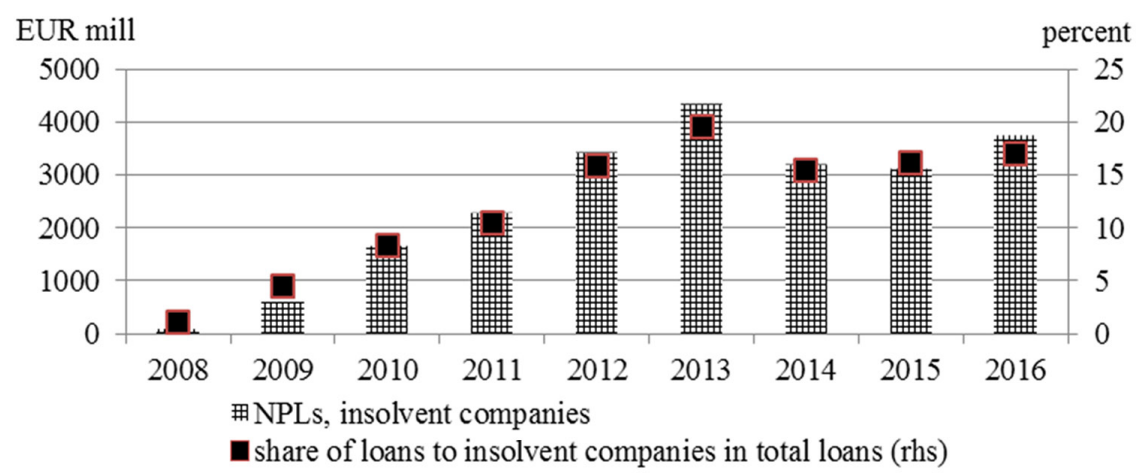

Source: National Bank of Romania

Figure 1. Non-performing loans generated by insolvent companies 
was severe (Mach, 2019). The situation in 2008 departed from a value of 2,894 insolvencies, continued growing to 5,175 in 2009 and decreased slightly in 2010 reaching a figure of 4,990 firms that entered in insolvency. In 2011, with the new dip of the economic situation, 5,910 firms entered in insolvency and in 2012 it rocketed to 8,095 till arrived to 9,143 in 2013. As the economy improved, the situation in 2014 changed and the number of firms involved in insolvencies decreased to 6,564. As it can be expected the number of insolvencies is quite related to the economic situation. If we correlate it with the GDP evolution, we find a negative relation (higher GDP is associated a lesser number of insolvencies) with a $\mathrm{R}^{2}=0.37$. Looking at the number of insolvencies along the last analysed year, 2016, we observe that the sector that concentrated a larger part of insolvencies was Trade, with 21.7 percent and Construction, with 19.0 percent of the cases. The available data do not allow to know how many employees were affected or which is the turnover of these companies, but we can say that most of them were micro-firms (69 percent of them had less than 10 employees) although the average size is larger than the one of the total population of firms in Spain and relatively young (18 percent was less than four years old). Concerning the legal regulation of bankruptcies in Spain, we can say that they are regulated by the Organic Law 8/2003, for the Reform of Bankruptcy Proceedings, and the Insolvency Act 22/2003.

\section{Related literature}

The existing literature has stressed that failure rate of firms in a country is mainly depending on two major factors:

First, the risk deriving from the management and capital adequacy. Based on previous research, failure is more likely for young firms than experienced firms (Altman, 1993) and also we expect a higher risk of bankruptcy for smaller firms because their limited access to the credit markets in comparison with larger firms (Bernanke \& Gertler, 1995).

Regarding the risk for young firms, the analysis of the survival rate of young companies in Europe shows that, on average, 44 percent survive for a five year period in comparison with an average death rate at 9 percent, for the business economies except the activities of holding companies. Besides, the average survival rate of enterprises born in Europe in 2009 and still active in 2014 shows that 44 percent of them survive for a five - year period. Moreover, companies born in countries such as Romania were most likely to survive up to the fifth year after their birth (around 60 percent of them), while Spain ran a higher risk of non-survival (less than 41 percent). Furthermore, the churn rate of employer enterprises stood at 19.02 percent in Romania, while in Spain it reached 18.01 percent. In fact, the correlation coefficient between the number of newly born enterprises over a five-year period and the numbers of death enterprises stood at 0.51 in Romania, compared with 0.12 in Czech Republic, 0.65 in Sweden, 0.79 in Spain and 0.88 in Slovenia during the interval 2009-2015. We note that the ratio of non-survivals is a good indication of deterioration of the business environment because of the death component, although it includes mergers or acquisitions.

The second important factor is the risk that the macroeconomic environment may generate. This element has been less investigated than the previous one. The paper focuses on this factor for Romania and Spain. 
One of the first research that considers macroeconomic determinants of corporate failure is Altman (1983) who found that business' failure is negatively affected by aggregate activity (measured by GNP), money market conditions and investor expectations. Wadhwani (1986) analysed the factors that explain corporate failures focusing on the hypothesis of the significant role for inflation. The author regressed the liquidation rate of companies on two macroeconomic variables and found that real wages, real prices, capital gearing, the level of interest rate (nominal and real) are statistically significant in UK for the period 1964-1981. A conclusion of this research is that credit markets do not allow firms to adjust their debt levels for inflation, as the nominal interest rate is found to be significant. Instead, Davis (1987) based on Wadhwani's previous work and considering 1969-1983 as a sample period (annual data) to test his hypothesis for United Kingdom, United States, Germany and Canada. The author the significant variables found for bankruptcy rate were: nominal interest rates, real input prices, real GNP and debt to GNP ratio (which was more significant than debt/ equity ratio). Bernanke and Gertler (1990) argued that financial fragility occurs when entrepreneurs who invest in new projects have a reduced amount of net assets. This model, where a decrease in borrowers' net worth exclude them from access to credit, creates a collapse in investment demand and amplifies financial instability.

Furthermore, H. Platt and M. Platt (1994) using cross-section correlated autoregressive model for the US and obtained evidence regarding the existence of a negative relationship between corporate failure and economic activity and it was positive with the cost level (real wages). In other study, Young (1995) analysed the effect of interest rate on corporate closures arguing that the major influence factor is "ex post" inflation and the difference between actual real interest rates and expected level of interest level. The dependent variable was bankruptcy rate and the explanatory variables were the growth rate of the number companies, real wages, real input prices, unexpected real interest rate changes, nominal interest rate, etc. He concluded that the significant variables are the unexpected real interest rate shocks, the changes in the number of companies, aggregate demand, real input prices, nominal interest rate (confirming Wadhwani's hypothesis) and the ratio of bank debt to the replacement cost of capital. Cuthbertson and Hudson (1996) focused only on compulsory liquidation of firms. They used two variables for measuring profitability: interest gearing and birth rate of companies. Considering quarterly data for the period 1972-1989 in U.K. they observed firm's profitability and birth rate to be significant explanatory factors.

Kiyotaki and Moore (1997) presented a model based on the role of assets as a production factor but also as collateral for credit. The correlation between asset prices and credit limits is a very powerful trigger and a transmission belt amplifying and extending macroeconomic instability. Moreover, Everet and Watson (1998) found that failure rate is positively correlated with interest rates and the rate of unemployment in Australia for the period 1974-1990. Also, they found that failure rates were found to be positively associated with lagged employment rates as well as with current and lagged retail sales level. The authors concluded that this indicates that "a strengthening economy may provide the trigger for an increase in voluntary business exits as individual proprietors seek to maximize the returns available to them on both their financial and human capital".

Vlieghe (2001) analysed U.K. data for the period 1975-1999 and found that the real interest rate is a significant long-run factor determinant of corporate bankruptcy. This research 
found a short run effect on company failure coming from property prices (a common and important collateral for corporate debt) and birth rate of companies, which is consistent with evidences which confirm that new companies are more likely to failure because lack of experience. On this study, those variables that capture the determinants of profits (real wages, aggregate demand, real interest rates) have a better explanatory power than aggregate profits. Also, significant factors in explaining corporate failures are debt to the replacement cost of assets and debt to GDP. In addition, Liu (2004) analysed U.K. corporate failure for the period 1966-1999 using an error-correction model. The main findings are that failure rates are associated with interest rates, credit, profits, price, and corporate birth rates both in the short run and in the long run. One important conclusion was that "interest rate appears to be an important factor influencing failure rates and can be used as a feasible policy instrument to reduce the incidence of corporate failures". It must be noted that, as Zhang, Bessler and Leatham (2013) propose, aggregate business' failures should not be considered as an exogenous variable, but that it also may cause (in the Granger sense) other macroeconomic variables. Specifically, this paper analysed the US firms with quarterly data in 1980-2004 through a Structural Vector Autoregression model. This study concluded that insolvencies are affected by a positive shock in interest rates but not from other variables such as the stock market; additionally, they found that bankruptcies causes a drop in interest rates.

On its part, Bhattacharjee, Higson, Holly and Kattuma (2009) studied the effect of macroeconomic environment on business exit considering that acquisitions and bankruptcies codetermined. Based on analysis of U.K. listed companies for a long period they concluded that macroeconomic instability has effect on bankruptcy hazard. Also, they got basis to support the hypothesis that the bankruptcy hazard is counter-cyclical. In case of the Swedish economy, Salman, Friedrichs and Shukur (2011) analysed the influence of macroeconomic variables on the failure of small companies considering quarterly data for the period 1986-2006. The authors found that bankruptcy rate is negatively affected by the level of industrial activity, money supply, changes in GNP and economic openness rate and positively related to the real wage. Harada and Kageyama (2011) analyse in the same mood the case of Japan finding that the overall macroeconomic situation (measured by GDP), as well as interest rates, are determinants of firms' failures as well as some financial variables. This paper presents a worthy extension over the previous literature since it distinguishes across the main sectors of the Japanese economy (manufacturing, construction and trade) confirming the aggregate results although showing a different time lag for each sector. In an environment closer to the countries to be analysed in this paper, Ziković(2016) recently analysed the macroeconomic elements that can explain firm's bankruptcies in Croatia along the period 2000-2011 throughout a Vector Error Correction Model, concluding that interest rates, as well as industrial production, have a short-term effect on insolvencies while unemployment has a long-run effect.

Tian and Yu (2017) developing a research using adaptive LASSO (least absolute shrinkage and selection operator) to select the default predictor variables finding that in different market infrastructure there is an advantage to use adaptively selected default predictor variables in bankruptcy prediction. Jones, Johnstone and Wilson (2017) examining the predictive performance of 16 classifiers starting with restrictive techniques (ex: logit and Linear discriminant analysis) to advanced (ex: neural network and SVM - Support vector machines) 
and very advanced statistical models (ex: AdaBoost and random forests). Based on a sample of US 990 corporate bankruptcies the main conclusion was recommendation for "new age" classifiers because of better predictions, practical appeal and good level of interpretability. In addition, Hernandez Tinoco, Holmes and Wilson (2018) using polytomous response logit methodology and observed that the combination between accounting, market and macroeconomic variables increasing the performances of the financial distress prediction model. Furthermore, Pham Vo Ninh et al. (2018) analysis a sample of 800 Vietnamese companies between 2003-2016 using financial ratios, market data and macroeconomic indicators. They find that there is a negative correlation between financial liquidity, productivity of invested capital, solvency, profitability and firm's dimension and the probability of default. The author's measuring the probability of default comparing EBIT and interest payments (EBIT < interest payments is equivalent with distress).

\section{The model}

The present study uses a model able to capture the interconnections between macroeconomic variables. In this regard, it is use a vector autoregressive (VAR) model, following the model described by Enache (2016). According to Boţel (2002), the main goal of the analysis of VAR type is to estimate the effects of various shocks on the system variables. Each variable is affected by own innovations, as well as by innovations in the other variables.

VAR models began to be used in economics in Sims's research studies (1980). Further on, Lutkepohl (1991), Hamilton (1994), Watson (1994), Hendry (1995), Waggoner and Zha (1999) updated the VAR techniques. The use of VAR models in financial data is present in numerous sources. Excellent are, for instance, Campbell, Lo and MacKinlay (1997), Leeper, Sims and Zha (1996) and Tsay (2001). Besides, it seems that the VAR methodology has got a renewed interest and further research paper have used it (see Qin (2010), for a survey). It seems an adequate methodology for the question to analyse macroeconomic shocks, which have been a common feature on the recent situation of most of the economies (Cavallo \& Ribba, 2015; Cloyne \& Hürgen, 2016 etc) and has been applied to the issue of bankruptcies (Zhang et al., 2013, Mamatzakis et al., 2016 etc.). An essential step in VAR analysis is the identification or orthogonalization of innovations.

In VAR models, the main decomposition methods encountered are: the Choleski recursive type, the Sims-Bernanke structural type and the Blanchard-Quah type with long-term constraints (Boţel, 2002). In this study the method proposed by Sims (1986) and Bernanke (1986) for short-therm shocks will be used.

\section{Data description and model estimation}

The empirical analysis investigates the reaction of the insolvency rate to the various shocks in the economies of Romania and Spain. In this regard, were estimated two VAR models. The variables that were considered are:

- insolvency rate (calculated as the number of newly insolvent companies during a quarter over the number of active companies at the end of the year); 
- interest rate of credit institutions on loans;

- retail trade, index of deflated turnover $(2010=100)$;

- investment rate (calculated as a weight of the gross capital formation in gross domestic product).

The availability of the data of the four series in the two countries constrained us to select the period from the $1^{\text {st }}$ quarter of 2008 to the $4^{\text {th }}$ quarter of 2016 . The time series were obtained from the databases of the National Trade Register Office of Romania, the National Institutes of Statistics of Romania and Spain, EUROSTAT and the National Bank of Romania.

The series used were expressed in natural logarithms and seasonally adjusted using the TRAMO/SEATS method. The augmented Dickey-Fuller test (Dickey \& Fuller, 1979) indicated that all variables are integrated of order I (Table 1).

Table 1. Tests of stationarity (Augmented Dickey-Fuller test)

\begin{tabular}{|c|c|c|c|c|}
\hline \multirow{2}{*}{ Variable } & \multicolumn{2}{|c|}{ Romania } & \multicolumn{2}{|c|}{ Spain } \\
\hline & Specification & t-statistic & Specification & t-statistic \\
\hline $\begin{array}{l}\text { ISR } \\
\text { d(ISR) }\end{array}$ & c & $\begin{array}{c}-1.058 \\
-7.945^{\star}\end{array}$ & c & $\begin{array}{l}-0.939 \\
-4.366^{*}\end{array}$ \\
\hline $\begin{array}{l}\text { INVR } \\
\text { d(INVR) }\end{array}$ & c & $\begin{array}{l}-0.817 \\
-3.761^{*}\end{array}$ & c & $\begin{array}{c}-1.63 \\
-4.867^{*}\end{array}$ \\
\hline $\begin{array}{l}\text { IR } \\
\text { d(IR) }\end{array}$ & $\mathrm{c}, \mathrm{t}$ & $\begin{array}{c}1.798 \\
-3.520^{* *}\end{array}$ & $\mathrm{c}, \mathrm{t}$ & $\begin{array}{l}-1.435 \\
-4.956^{*}\end{array}$ \\
\hline $\begin{array}{l}\text { RT } \\
\text { d(RT) }\end{array}$ & c & $\begin{array}{l}-1.789 \\
-4.643^{*}\end{array}$ & $c, t$ & $\begin{array}{c}-1.722 \\
-3.602^{* *}\end{array}$ \\
\hline
\end{tabular}

Notes: The test contain constant $(\mathrm{c})$, constant and trend $(\mathrm{c}, \mathrm{t})$. Critical values for the augmented Dickey-Fuller test: (i) with constant: $1 \%:-3.63 ; 5 \%:-2.95 ; 10 \%:-2.61$; (ii) with trend and constant: $1 \%$ : $-4.24 ; 5 \%$ : $-3.54 ; 10 \%$ : -3.20 . (MacKinnon (1996). The series is stationary if the null hypothesis is rejected by the ADF test $\left(\mathrm{H}_{0}\right.$ : the series has a unit root). The ${ }^{\star},{ }^{*}$ indicate the rejection of the null hypothesis at a significance level of $1 \%, 5 \%$, respectively.

Selection of the most adequate number of lags in the estimation of the two models was performed on the basis of the Akaike (1974, 1976), Hannan and Quinn (1979) and Schwarz (1978) informational criteria. The Akaike and Hannan and Quinn criteria suggested 4 lags, but the VAR is not stable in Spain. Since both VARs are stable and the results of tests on the residues have shown that they are constantly varied and are not autocorrelated, we preferred the Schwarz criterion, which selected a single lag. Normality has only been confirmed for the model of Romania, but according to Neagu and Mărgărit (2005) that cited Lutkepohl and Reimers (1992), the estimation of a VAR is not strictly related to the hypothesis of normality. The order of the integration of the time series imposed to utilize of the Johansen test (see Johansen \& Juselius, 1990) in the analysis. It validated, for each of the two models, the presence of a single cointegration relationship between ISR, INVR, IR and RT at a significance level of 5 percent (It was considered the cointegration based on a linear deterministic trend, Table 2). 
Table 2. Johansen cointegration test

\begin{tabular}{|c|c|c|c|c|}
\hline \multirow{2}{*}{ Null hypothesis } & \multicolumn{2}{|c|}{ Romania } & \multicolumn{2}{c|}{ Spain } \\
\cline { 2 - 5 } & $J_{\text {trace }}$ & $J_{\max }$ & $J_{\text {trace }}$ & $J_{\max }$ \\
\hline \multirow{2}{*}{$\mathrm{r}=0$} & 62.7954 & 39.2740 & 50.5302 & 28.0968 \\
& $(0.0001)$ & $(0.0002)$ & $(0.0274)$ & $(0.0430)$ \\
\hline \multirow{2}{*}{$\mathrm{r} \leq 1$} & 23.5214 & 15.3853 & 22.4334 & 13.4816 \\
& $(0.0620)$ & $(0.1112)$ & $(0.2750)$ & $(0.4089)$ \\
\hline $\mathrm{r} \leq 2$ & 8.1361 & 7.7060 & 8.9517 & 6.7207 \\
& $(0.2263)$ & $(0.1941)$ & $(0.3699)$ & $(0.5227)$ \\
\hline $\mathrm{r} \leq 3$ & 0.4300 & 0.4300 & 2.2311 & 2.2311 \\
& $(0.5754)$ & $(0.5754)$ & $(0.1353)$ & $(0.1353)$ \\
\hline
\end{tabular}

Note: p-value in parenthesis ( ).

The structure of the contemporary relationships between the variables (matrix A) follows the general form proposed by Boţel (2002) and it is presented in Table 3.

Table 3. A matrix structure

\begin{tabular}{|c|c|c|c|c|}
\hline & ISR & INVR & IR & RT \\
\hline ISR & 1 & 1 & 1 & 1 \\
\hline INVR & 0 & 1 & 1 & 0 \\
\hline IR & 0 & 0 & 1 & 0 \\
\hline RT & 0 & 1 & 1 & 1 \\
\hline
\end{tabular}

The established restrictions show that ISR is influenced by INVR, IR and RT over a time horizon of a quarter. Also, INVR influences RT, and IR influences INVR and RT. In addition, each variable is influenced by itself.

\section{Results and interpretations}

According to the estimated models (Onete, 2003), it could be simulated as IRF, the ISR reactions to the shocks coming from all 4 variables (Figure 2).

As it can be seen, ISR reacts positively and immediately to its own shocks, both in the case of Romania and in the case of Spain, their effects being statistically significant during the first 6 and 5 quarters, respectively. The relationships predicted by economic theory are confirmed for IR and RT with ISR in the two countries. As it was expected, ISR responds positively to IR shocks and negatively to RT shocks. It should be noted that, in Romania, the effects of IR, as well as the effects on the first 7 quarters of the RT, are significantly different from zero (the confidence interval does not include the zero value). In contrast, in Spain, the effects of IR are statistically significant between Q2 and Q7, while those of RT are significant in the first 3 quarters. The response that ISR shows to INVR shocks is smaller in Romania than in Spain. The sign of the relationship is the anticipated one, namely negative in the first 9 quarters in Spain and starting in the second quarter in Romania. It can be noticed that 
Response to Structural One S. D. Innovations \pm 2 S. E.

Romania. Response of ISR Romania. Response of ISR Romania. Response of ISR to Shock ISR

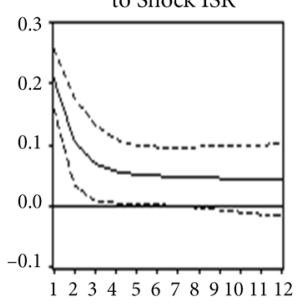

to Shock INVR

to Shock IR
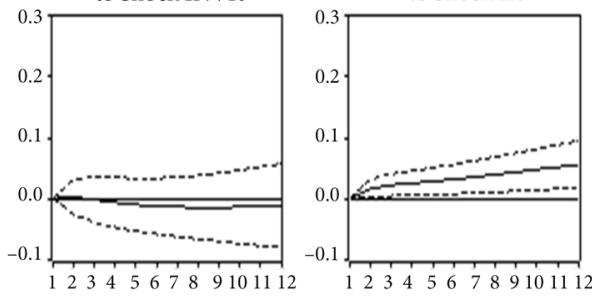

Romania. Response of ISR to Shock RT

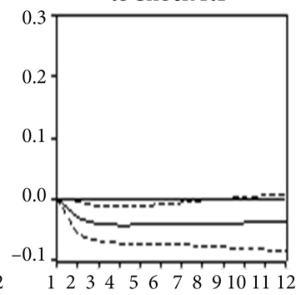

Response to Structural One S. D. Innovations \pm 2 S. E.
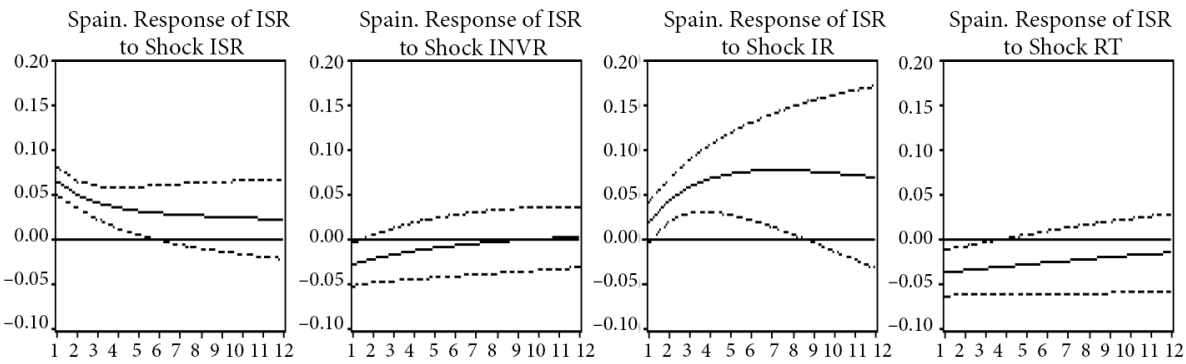

Figure 2. The impulse response functions

INVR shocks have statistically significant influences only in Spain during the first quarter.

The variance decomposition (Figure 3) shows that in Romania, at all time horizons, IR was the main determinant of the ISR variation, beyond its own innovations. In contrast, in Spain, unlike in Romania, IR becomes the second factor from the point of view of significance after its own innovations in horizons of over 2 quarters.
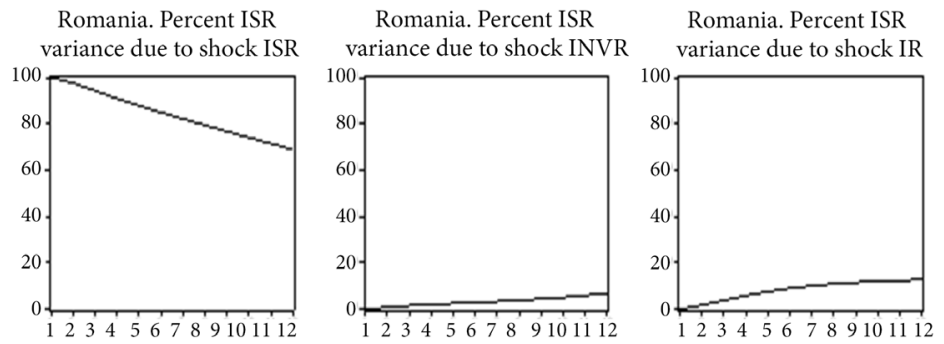

Romania. Percent ISR

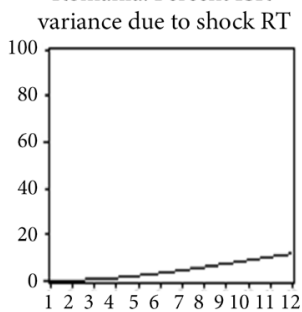

Spain. Percent ISR
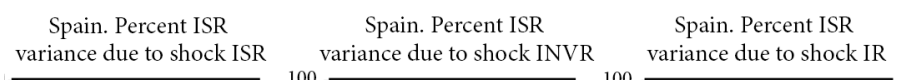

Spain. Percent ISR
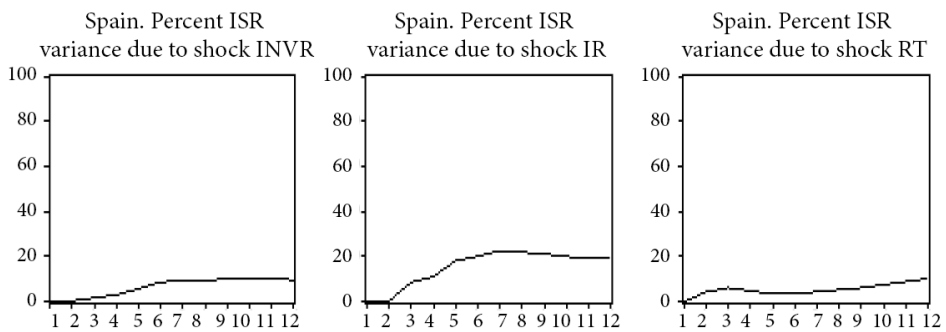

Figure 3. Variance decomposition 
Table 4. Granger causality test

\begin{tabular}{|c|c|c|c|c|c|}
\hline \multirow{4}{*}{ Romania } & & ISR & INVR & IR & RT \\
\cline { 2 - 6 } & ISR & & 0.38656 & 0.14706 & 0.22684 \\
\cline { 2 - 6 } & INVR & 0.12278 & & $\mathbf{0 . 0 0 0 0 4}$ & 0.05883 \\
\cline { 2 - 6 } & IR & $\mathbf{0 . 0 3 4 7 1}$ & 0.66383 & & $\mathbf{0 . 0 0 0 0 1}$ \\
\cline { 2 - 6 } & RT & $\mathbf{0 . 0 2 3 8 7}$ & 0.26287 & $\mathbf{0 . 0 0 4 3 4}$ & \\
\hline \multirow{4}{*}{ Spain } & ISR & & 0.00007 & 0.79688 & 0.69891 \\
\cline { 2 - 6 } & INVR & 0.10692 & & 0.93530 & $\mathbf{0 . 0 0 0 4 0}$ \\
\cline { 2 - 6 } & IR & $\mathbf{0 . 0 0 0 0 2}$ & 0.50658 & & 0.09762 \\
\cline { 2 - 6 } & RT & $\mathbf{0 . 0 4 9 5 1}$ & $\mathbf{0 . 0 0 0 4 0}$ & 0.54571 & \\
\hline
\end{tabular}

Notes: 1 . The basic hypothesis tested is: the variable in the line is not Granger caused by the variables in the columns. 2. The figures represent the probability (p-value). 3 . The figures in bold indicate the rejection of the basic hypothesis at a 5 percent significance level.

Finally, following the exposed methodology, Granger causality tests were applied. The results are presented in Table 4.

Thus, it was noted that both in Romania and in Spain, INVR does not Granger cause ISR. In contrast, in both countries IR and RT Granger cause ISR. Therefore, it can be said that the influences of the two variables on the ISR are predictable.

These results were achieved for an environment where, in Romania in the period 20092016, the share of companies without investments in the total non-financial companies remained around the level of 76.0-78.7 percent. Under these circumstances, into a context of prevailing rivalry (Vasiliu, 2008), the investment rate of non-financial companies (calculated as a ratio between the cash flows attributable to the investment activity and the total assets) was 6.67 percent in 2009, followed by a downward trend of up to 4.55 percent in 2010, then remaining during the period 2011-2016 in a range of 5.7-6.56 percent. In addition, the ability of companies to cover their interest costs from revenues has varied along the period 2008-2016. Thus, the interest coverage rate ((gross profit+interest expenditures)/interest expenditures), that was 3.96 percent in June 2008, reduced to 1.07 percent in June 2009, 1.8 percent in December 2012 and 5.41 percent in December 2016. According to the Survey on the access to finance of the non-financial corporations of the National Bank of Romania for the period October 2015-March 2016, the average interest rate on RON loans was between 3 and 5 percent, while the one for EUR loans was between 2 and 4 percent. Under these conditions, 60 percent of the companies (the sample for the Survey includes roughly 10,500 nonfinancial corporations) said they did not need additional bank financing, as the activity and / or the credit repayment capacity would be affected by an increase in the cost of financing by up to 3 percentage points for both types of credits. Moreover, the arrears of non-financial companies towards their own suppliers increased from EUR 10.71 billion in 2008 to EUR 13.15 billion in 2012, followed by a downward trend of up to EUR 10.42 billion in 2016. At the same time, the average duration between the delivery of the product/service and the receipt of its value increased from 82 days in December 2008 to 103 days in December 2012, then decreasing to 102 days in June 2015. 
Meanwhile, in Spain the situation is different. It must be noted that in Spain the main data source to analyse the situation of firms is the Central de Balances del Banco de España (CBBE). CBBE is the Spanish branch of the Bank for the Accounts of Companies Harmonised that collect annual accounts of non-financial companies in eleven EU countries. It covers around 660,000 firms which is over 50 percent of total firms, over 75 percent of firms with more than 50 employees, and around one third of the domestic value added (see Banco de España (2016) for details). According this database the investments (measured as the increase in the value of material investments) which was positive in 2008 became negative in 2014; this is, firms were not only increasing the value of their material and real estate assets but its value was decreasing. Concerning their financial expenditures, the value moved around 4 percent of the value of the production. In 2008, it supposed 5 percent, decreasing one percentage point in 2009, continuing the reduction in 2010, but in 2011 it started to increase in 0.4 percentage points and continued increasing till 2013 when it decreased one tenth and 2014 in 0.3 percentage points. So we observe a situation of stress in the financial side of the firms' accounts between 2011 and 2013 that for sure worsened the situation of the firms. But more important that the interest rate was the lack of access to external financial funds. According the same database, between 2008 and 2014 (the studied period) the long term financial funds that non-financial firms had from banks in their balance sheets, decreased all the years, except in 2009 when it increased in two percentage points. This situation of lack of long term funds from banks, for sure, increased the problems of firms leading some of them to a bankruptcy situation. If instead of analysing the weight of long term financial resources that banks provide to non-financial firms, we focus on the short term ones, the landscape is the same with the only increase in 2008. Concerning the delays in paying debts (from non-financial firms to banks and credit institutions) we see that it increased, quarter by quarter till 2009Q1 when it started to decrease, but along 2010 it increased again, although in 2011Q1 started a decrease trend that continues without interruption till 2014. So, this other indicator of the financial stress of the non-financial firms is also showing that they suffered of an increasing pressure in the first years of the analysed period, with a certain moderation in 2010, a new upward movement, and in 2011 the situation started to improve.

\section{Conclusions}

The statistical analysis has concluded that ISR reacts positively to IR shocks, in both countries, with a longer effect in Romania than in Spain. It must be mentioned that Spain, as a member of the European Monetary Union, cannot design and implement an autonomous monetary policy, while Romania can, given it is not a member. The observed sensibility of firms' bankruptcies to interest rates compels to consider this additional consequence of EMU membership. Given that the European-wide monetary policy hardly will adapt to the domestic situation of peripheral countries (as Spain or eventually Romania) real convergence must be achieved before becoming member of EMU; otherwise the European monetary policy (adapted to the core of the EMU) can be devastating for the productive sector of those countries which experience a different situation from those ones that justify the adopted monetary policies. The influence of interest rates over the firms' situation, till the point of affecting its 
solvency is one of the most common results that previous research has found and it must be stressed that microeconomic analyses (see, for example Guariglia et al. (2016), for an analysis with a panel of UK firms in 2000-2009) confirm its importance. Moreover, ISR responds negatively to RT shocks both in the case of Romania and in the case of Spain, their effects being statistically significant during the first 7 and 3 quarters, respectively. This result reveals that Romanian firms are more sensitive to the macroeconomic situation of the economy, probably due to its smaller size. Additionally, ISR reacts negatively to INVR shocks in the first 9 quarters in Spain and starting in the second quarter in Romania. The effects of INVR are significantly different from zero only in Spain during the first quarter. In Spain, on the one hand, a large part of manufacturing sector is concentrated in production goods and machine-tools, as the figures of exports proof. So, a decrease in the investment will reduce the market of a large part of the economy. On the other hand, the economic crisis was characterized by the end of a building bubble, that reduced notably the construction sector (from over 200,000 new licenses to construct new buildings a year in 2005-2006 to slightly less than 100,000 in 2008 and less than 25,000 in 20014-2015). On its part, civil building suffered a huge reduction too, due to the shortcuts in public budgets. Given that the output of the construction sector is mostly considered Capital Formation in National Accounts is not surprising that the evolution of this sector, and then the investments, affects so much to the number of firms in the sector. Instead, in Romania only about 25 percent of the companies are investing, and the average investment value is around 90,000 EUR/firm - too low for new capacities. Furthermore, we noticed that, both in Romania as well as in Spain, the ISR variation is almost entirely influenced by its own innovations and IR shocks at a horizon of four quarters. In addition, the influence of INVR on IR is not anticipatory.

These results lead to further research lines. Firstly, it confirms the value of comparisons among countries in order to highlight differences on the economic situation, institutional characteristics and firms' survival. Secondly, given the special circumstances of this period, further research on situations where interest rates and financial markets are not so stressed could reveal other structural features for the survival of firms.

\section{References}

Akaike, H. (1974). A new look at the statistical model identification. IEEE Transactions on Automatic Control, 19(6), 716-723. https://doi.org/10.1109/TAC.1974.1100705

Akaike, H. (1976). Canonical correlation analysis of time series and the use of an information criterion. In R. K. Mehra \& D. G. Lainotis (Eds.), System identification: Advances and case studies (pp. 27-96). Academic Press. https://doi.org/10.1016/S0076-5392(08)60869-3

Altman, E. (1983). Why businesses fail. Journal of Business Strategy, 3(4), 15-21. https://doi.org/10.1108/eb038985

Altman, E. (1993). Company financial distress and bankruptcy (2 ${ }^{\text {nd }}$ ed.). Wiley \& Sons.

Anghel, I. (2002). Falimentul radiografie si predictie. Economica.

Banco de España (2016). Central de Balances. Resultados anuales de las empresas no financieras, Spain. Ed. Banco de España. https://www.bde.es/bde/es/areas/cenbal/ 
Beca, M., \& Nișulescu-Ashrafzadeh, I. (2014). The impact of the economic crisis on the corporate insolvency's evolution in Romania. Procedia - Social and Behavioral Sciences, 109, 891-895. https://doi.org/10.1016/j.sbspro.2013.12.560

Bernanke, B., \& Gertler, M. (1990). Financial fragility and economic performance. Quarterly Journal of Economics, 105, 87-114. https://doi.org/10.2307/2937820

Bernanke, B., \& Gertler, M. (1995). Inside the black box: The credit channel of monetary policy transmission. Journal of Economics Perspectives, 9(4), 27-48. https://doi.org/10.1257/jep.9.4.27

Bernanke, B. (1986). Alternative explanations of money-income correlation. Carnegie-Rochester Conference Series on Public Policy, 25, 49-99. https://doi.org/10.1016/0167-2231(86)90037-0

Bhattacharjee, A., Higson C., Holly, S., \& Kattuma, P. (2009). Macroeconomic instability and business exit: Determinants of failures and acquisitions of UK firms. Economica, 76(301), 108-131. https://doi.org/10.1111/j.1468-0335.2007.00662.xx

Boțel, C. (2002). Cauzele inflaţiei în România, iunie 1997-august 2001. Analiză bazată pe vectorul autoregresiv structural. Caiet de studii nr. 11. Banca Naţională a României.

Campbell, J. A. Lo, \& MacKinlay, C. (1997). The econometrics of financial markets. Princeton University Press. https://doi.org/10.1515/9781400830213

Cavallo, A., \& Ribba, A. (2015). Common macroeconomic shocks and business cycle fluctuations in Euro area countries. International Review of Economics \& Finance, 38, 377-392. https://doi.org/10.1016/j.iref.2015.03.006

Cloyne, J., \& Hürgen, P. (2016). The macroeconomic effects of monetary policy: A new measure for the United Kingdom. American Economic Journal: Macroeconmics, 8(4), 75-102. https://doi.org/10.1257/mac.20150093

Cuthbertson, K., \& Hudson, J. (1996). The determinants of compulsory liquidations in the UK. The Manchester School, 64(3), 298-308. https://doi.org/10.1111/j.1467-9957.1996.tb00487.x

Dăianu, D., Pîslaru, D., \& Voinea, L. (2004). Features of bankruptcy in the Romanian economy: Comparative perspective and analysis. Pre-Accession Impact Studies II, 8. European Institute of Romania, Bucharest. http://ier.gov.ro/en/publication/study-no-8-features-of-bankruptcy-in-the-romanianeconomy-comparative-perspective-and-analysis/

Davis, E. P. (1987). Rising sectoral debt/income ratios: A cause for concern? BIS Economic Papers, No. 20. https://www.bis.org/publ/econ20.htm

Dickey, D. A., \& Fuller, W. A. (1979). Distribution of the estimators for autoregressive time series with a unit root. Journal of the American Statistical Association, 74(366), 427-431. https://doi.org/10.2307/2286348

Došenović Bonča, P., Tajnikar, M., Ponikvar, N., \& Mörec, B. (2018). Firm growth types and key macroeconomic aggregates through the economic cycle. Journal of Business Economics and Management, 19(1), 138-153. https://doi.org/10.3846/16111699.2017.1422798

Enache, C. (2016). Metode cantitative in studiul fenomenelor economice. ASE, Bucuresti.

Everett, J., \& Watson, J. (1998). Small business failure and external risk factors. Small Business Economics, 11(4), 371-90. https://doi.org/10.1023/A:1008065527282

Fisher, I. (1933). The debt-deflation theory of great depressions. Econometrica, 1(4), 337-357. https://doi.org/10.2307/1907327

Gonzalez, M., Nafe, J., \& Rubio, G. (2018). Macroeconomic determinants of stock market betas. Journal of Empirical Finance, 45, 26-44. https://doi.org/10.1016/j.jempfin.2017.10.003

Guariglia, A., Spaliara, M. E., \& Tsoukas, S. (2016). To what extent does the interest burden affect firm survival? Evidence from a panel of UK firms during the recent financial crisis. Oxford Bulletin of Economics and Statistics, 78(4), 576-594. https://doi.org/10.1111/obes.12120

Hamilton, J. D. (1994). Time series analysis. Princeton University Press. 
Hannan, E. J., \& Quinn, B. G. (1979). The determination of the order of an autoregression. Journal of the Royal Statistical Society, Series B, 41(2), 190-195. https://doi.org/10.1111/j.2517-6161.1979.tb01072.x

Harada, N., \& Kageyama, N. (2011). Bankruptcy dynamics in Japan. Japan and the World Economy, 23(2), 119-128. https://doi.org/10.1016/j.japwor.2011.01.002

Hendry, D. F. (1995). Dynamic econometrics. Oxford University Press. https://doi.org/10.1093/0198283164.001.0001

Hernandez Tinoco, M., Holmes, P., \& Wilson, N. (2018). Polytomous response financial distress models: The role of accounting, market and macroeconomic variables. International Review of Financial Analysis, 59, 276-289. https://doi.org/10.1016/j.irfa.2018.03.017

Johansen, S., \& Juselius, K. (1990). Maximum likelihood estimation and inference on cointegration with applications to the demand for money. Oxford Bulletin of Economics and Statistics, 52(2), 169-210. https://doi.org/10.1111/j.1468-0084.1990.mp52002003.x

Jones, S., Johnstone, D., \& Wilson, R. (2017). Predicting corporate bankruptcy: An evaluation of alternative statistical frameworks. Journal of Business Finance \& Accounting, 44(1-2), 3-34. https://doi.org/10.1111/jbfa.12218

Kiyotaki, N., \& Moore, J. (1997). Credit cycles. Journal of Political Economy, 105(2), 211-248. https://doi.org/10.1086/262072

Kuběnka, M., \& Myšková, R. (2019). Obvious and hidden features of corporate default in bankruptcy models. Journal of Business Economics and Management, 20(2), 368-383. https://doi.org/10.3846/jbem.2019.9612

Leeper, E. M., Sims, C. A., \& Zha, T. (1996). What does monetary policy do? Brookings Papers on Economic Activity, 1996(2), 1-78. https://doi.org/10.2307/2534619

Liu, J. (2004). Macroeconomic determinants of corporate failure: Evidence from the UK. Applied Economics, 36(9), 939-945. https://doi.org/10.1080/0003684042000233168

Lutkepohl, H., \& Reimers, H. E. (1992). Impulse response analysis of cointegrated systems, Journal of Economics Dunamycs and Control, 16, 53-78. https://doi.org/10.1016/S0304-4076(97)00037-7

Lutkepohl, H. (1991). Introduction to multiple time series analysis. Springer-Verlag. https://doi.org/10.1007/978-3-662-02691-5

Mach, Ł. (2019). Measuring and assessing the impact of the global economic crisis on European real property market. Journal of Business Economics and Management, 20(6), 1189-1209. https://doi.org/10.3846/jbem.2019.11234

MacKinnon, J. G. (1996). Numerical distribution functions for unit root and cointegration tests. Journal of Applied Econometrics, 11(6), 601-618. https://doi.org/10.1002/(SICI)1099-1255(199611)11:6<601::AID-JAE417>3.0.CO;2-T

Mamatzakis, E., Matouse, R., \& Vu, A. N. (2016). What is the impact of bankrupt and restructured loans on Japanese bank efficiency? Journal of Banking \& Finance, 72, S187-S202. https://doi.org/10.1016/j.jbankfin.2015.04.010

National Bank of Romania. (2016). Survey on the access to finance of the non-financial corporations in Romania and their capacity to withstand adverse financial conditions (Edition June 2016). http://www.bnro.ro/Publicatii-periodice-204.aspx

Neagu, F., \& Mărgărit, A. (2005). Riscurile pentru stabilitatea financiara din Romania generate de sectorul populatie. Caiet de studii nr. 14. Banca Naţională a României.

Onete, B. (2003). Sisteme informatice: elemente fundamentale. ASE, Bucuresti.

Pham Vo Ninh, B., Do Thanh, T., \& Vo Hong, D. (2018). Financial distress and bankruptcy prediction: An appropriate model for listed firms in Vietnam. Economic Systems, 42(4), 616-624. https://doi.org/10.1016/j.ecosys.2018.05.002 
Platt, H., \& Platt, M. (1994). Business cycle effects on state corporate failure rates. Journal of Economics and Business, 46(2), 113-127. https://doi.org/10.1016/0148-6195(94)90005-1

Qin, D. (2010). Rise of VAR modelling approach. Journal of Economic Surveys, 25(1), 156-174. https://doi.org/10.1111/j.1467-6419.2010.00637.x

Salman, K., Friedrichs, Y., \& Shukur, G. (2011). The determinants of small manufacturing firms: Assessing the macroeconomic factors. International Bussiness Research, 4(3), 22-32. https://doi.org/10.5539/ibr.v4n3p22

Schwarz, G. (1978). Estimating the dimension of a model. Annals of Statistics, 6(2), 461-464. https://doi.org/10.1214/aos/1176344136

Sims, C. A. (1980). Macroeconomics and reality. Econometrica, 48(1), 1-48. https://doi.org/10.2307/1912017

Sims, C. A. (1986). Are forecasting models usable for policy analysis? Quarterly review (Federal Reserve Bank of Minneapolis), Winter, 2-16. https://doi.org/10.21034/qr.1011

Smaranda, C. (2014). Scoring functions and bankruptcy prediction models - case study for Romanian companies. Procedia Economics and Finance, 10, 217-226. https://doi.org/10.1016/S2212-5671(14)00296-2

Stiglitz, J. (2003). Bankruptcy laws: Basic economic principles. In S. Claessens, S. Djankov, \& A. Mody (Eds.), Resolution of financial distress: An international perspective on the design of bankruptcy laws (pp. 1-23). The World Bank.

Tian, S., \& Yu, Y. (2017). Financial ratios and bankruptcy predictions: An international evidence. International Review of Economics \& Finance, 51(C), 510-526. https://doi.org/10.1016/j.iref.2017.07.025

Tsay, R. (2001). Analysis of financial time series. John Wiley \& Sons.

Vasiliu, C. (2008). Warehousing - activity which contribute to supply chain performance. The Amfiteatru Economic Journal, 10(24), 94-10.

http://www.amfiteatrueconomic.ase.ro/arhiva/pdf/no24/articol_fulltext_pag94.pdf

Vlieghe, G. (2001). Indicators of fragility in the UK corporate sector (Bank of England working papers 146). https://doi.org/10.2139/ssrn.293186

Wadhwani, S. (1986). Inflation, bankruptcy, default premia and the stock market. The Economic Journal, 96(381), 120-138. https://doi.org/10.2307/2233429

Waggoner, D. F., \& Zha, T. (1999). Conditional forecasts in dynamic multivariate models. Review of Economics and Statistics, 81(4), 639-651. https://doi.org/10.1162/003465399558508

Watson, M. (1994). Vector autoregressions and cointegration. In R. F. Engle \& D. McFadden (Eds.), Handbook of Econometrics (Vol. 4). Elsevier Science Ltd. https://doi.org/10.1016/S1573-4412(05)80016-9

Young, G. (1995). Company liquidations, interest rates and debt. The Manchester School, 63(1), 57-69. https://doi.org/10.1111/j.1467-9957.1995.tb01448.x

Zhang, J., Bessler, D. A., \& Leatham, D. J. (2013). Aggregate business failures and macroeconomic conditions: A VAR look at the US between 1980 and 2004. Journal of Applied Economics, 16(1), 179-202. https://doi.org/10.1016/S1514-0326(13)60008-2

Ziković, I. T. (2016). Modelling the impact of macroeconomic variables on aggregate corporate insolvency: Case of Croatia. Economic Research-Ekonomska Istrazivanja, 29(1), 515-528. https://doi.org/10.1080/1331677X.2016.1175727 